\title{
A new species of Arene (Vetigastropoda, Areneidae) from Canopus Bank, off NE Brazil
}

\author{
Daniel Caracanhas Cavallari ${ }^{1}$ \& Luiz Ricardo Lopes de Simone ${ }^{2}$ \\ ${ }^{1}$ Universidade de São Paulo (USP), Faculdade de Filosofia, Ciências e Letras de Ribeirão Preto (FFCLRP). Ribeirão Preto, SP, Brasil. \\ ORCID: 0000-0003-3104-6434. E-mail: dccavallari@usp.br \\ 2 Universidade de São Paulo (USP), Museu de Zoologia (MZUSP). Avenida Nazaré, 481, Ipiranga, 04263-000, São Paulo, SP, Brasil. \\ ORCID: 0000-0002-1397-9823. E-mail: Irsimone@usp.br
}

\begin{abstract}
Arene lychee sp. nov. is described from Canopus Bank, a seamount located 190 km off Fortaleza, Ceará, NE Brazil $\left(02^{\circ} 14^{\prime} 25^{\prime \prime} S, 38^{\circ} 22^{\prime} 50^{\prime \prime} \mathrm{W}\right)$, based on shell morphology. The species is characterized by a large, trochiform shell; color ranging from intense reddish to white (darker on spiral cords, lighter at base) with a yellow apex; sculpture of 3-8 wide spiral cords with large scale-like spines; cords separated by deep interspaces with similar width, and interspaces sculptured by closely-packed, thin axial growth lines.
\end{abstract}

Key-Words. Angarioidea; Biodiversity; Gastropoda.

\section{INTRODUCTION}

The family Areneidae has been recently erected to remedy nomenclatural issues and to reflect recent molecular phylogenetic hypotheses of relationships within the Vetigastropoda (Williams et al., 2008; McLean, 2012). As it is currently understood, the family exclusively accommodates species previously belonging to Liotiidae Gray, 1850. The Areneidae are characterized by colorful shells (as opposed to the whitish Liotiidae) with dominant spiral sculpture, a tangential aperture with denticles and a lip preceded by a short phase of whorl expansion (McLean, 2012). The group currently includes the African genus Cinysca Kilburn, 1970 and the Atlantic-Pacific Arene Adams \& Adams, 1854 , which is represented in Brazil by at least nine species (Rios, 2009).

Canopus Bank is a seamount located $\sim 190 \mathrm{~km}$ off Ceará state, NE Brazil $\left(02^{\circ} 14^{\prime} 25^{\prime \prime} \mathrm{S}, 38^{\circ} 22^{\prime} 50^{\prime \prime} \mathrm{W}\right.$, ca. 50-600 m depth), which harbors an impressive diversity of invertebrate species. The local substrate is mostly biogenic, presenting relatively large, calcareous particles consisting of mixed animal remains such as fragmentary hard corals, crustaceans, echinoderms, and mollusk shells. Studies on sediment samples from Canopus collected in 2005 have revealed a remarkable number of new taxa. This includes 17 new gastropod species belonging to 12 different families, most of which were described based on empty shells (e.g., Abbate \& Cavallari, 2013; Simone \& Cunha,
2014; Fernandes et al., 2015). In the present study, we formally describe a new species of Arene from Canopus stemming from a broader review of the local vetigastropod fauna (Cavallari \& Simone, unpublished data).

\section{MATERIAL AND METHODS}

The samples examined herein were collected in Canopus Bank in August 2005 by J. Coltro and P.M.S. Costa at 200-260 m depths. They comprise empty, dried out shells held at the malacological collection of the Museu de Zoologia da Universidade de São Paulo (MZSP, São Paulo, Brazil). Taxonomy and terminology follow Simone (2011). Specimens were photographed and measured under a Zeiss SteREO Discovery V12 stereomicroscope coupled with a Zeiss AxioCam MRc5 digital camera. Shells were coated with gold and examined with a scanning electron microscope at the MZSP.

\section{SYSTEMATICS}

\section{Arene lychee sp. nov. (Figure 1A-H)}

Type material: Holotype MZSP 70301. Paratypes: MZSP 93482, 2 shells (juveniles), MZSP 93501, 2 shells, MZSP 135314, 4 shells, same data as holotype, $200 \mathrm{~m}$ depth (viii/2005). 


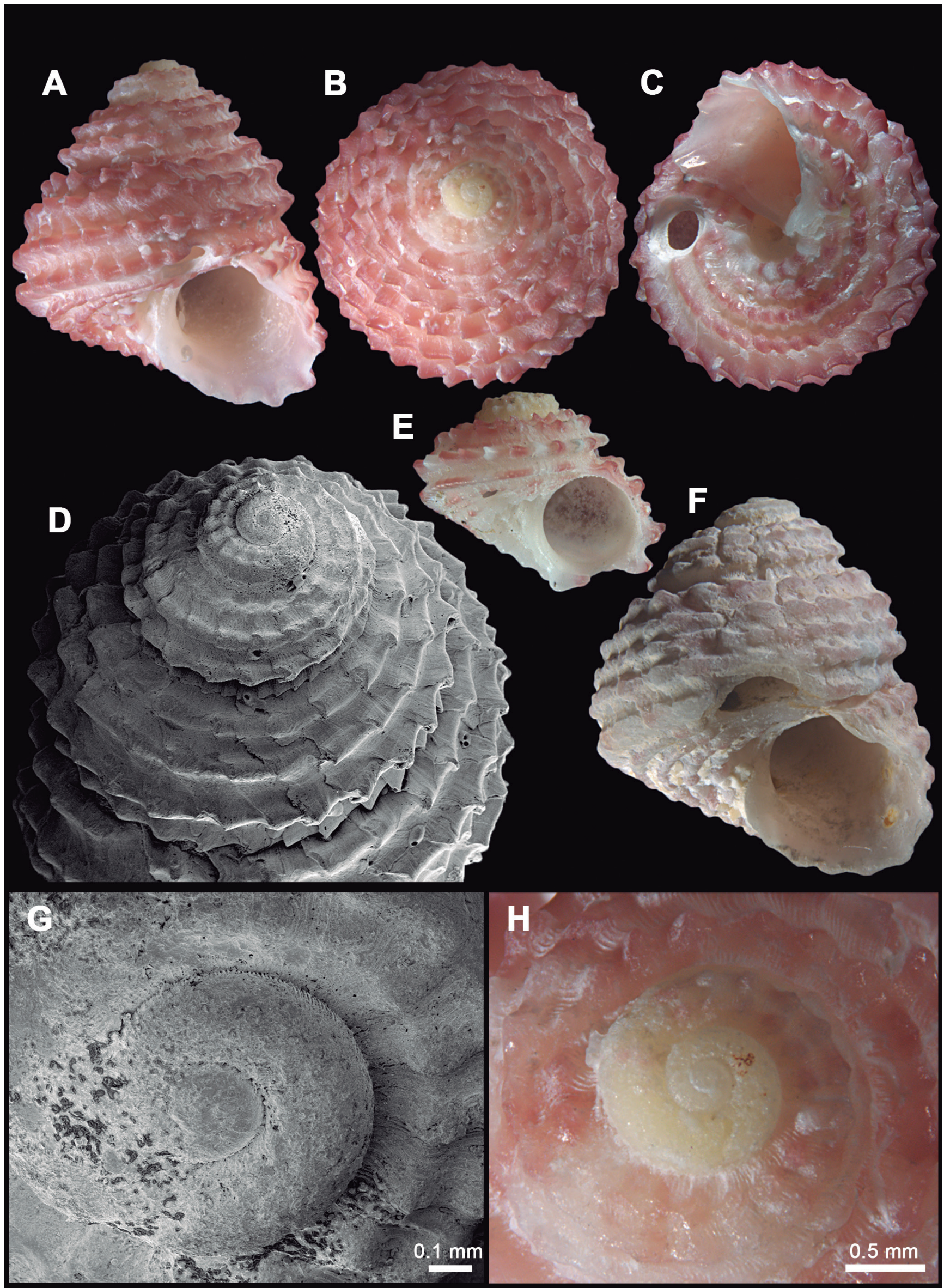

Figure 1. Arene lychee shell morphology. (A-D) Holotype MZSP 70301; (A) apertural view (H=8.3 mm, D =7.5 mm); (B) apical view; (C) umbilical view; (D) apical, slightly lateral view, SEM; (E) Paratype MZSP 135314, juvenile specimen ( $\mathrm{H}=3.6 \mathrm{~mm}, \mathrm{D}=4.7 \mathrm{~mm}$ ); (F) Paratype MZSP 135314, apertural view (H=7.2 mm, $\mathrm{D}=6.5 \mathrm{~mm}) ;(\mathrm{G})$ Holotype protoconch, SEM, apical view $($ scale $=0.1 \mathrm{~mm}) ;(\mathrm{H})$ same, detail of the apex (scale $=0.5 \mathrm{~mm})$. 
Type locality: Brazil, Ceará, off Fortaleza, Canopus Bank, $02^{\circ} 14^{\prime} 25^{\prime \prime} \mathrm{S}, 38^{\circ} 22^{\prime} 50^{\prime \prime} \mathrm{W}, 260 \mathrm{~m}$.

Diagnosis: Shell relatively large, trochiform. Teleoconch sculptured by 3 wide spiral cords (increasing in number, up to 8 on body whorl) bearing large, mostly hollow, scale-like spines and closely-packed, thin axial growth lines, more visible in interspaces; cords separated by equally wide, deep interspaces. Color from white to intense red, darker on spiral cords, and lighter at base; apex yellow.

Description: Shell relatively large (H 7-9 mm), trochoid, slightly taller than wide (H/D 1.1), with 5 convex whorls; color strong red to white, darker on spiral cords and lighter at base (juveniles are often lighter colored overall; Fig. 1E); apex yellow (Fig. 1B, H). Spire medium-sized (height $\sim 1 / 3$ of shell height); apex rounded; spire angle $\sim 85^{\circ}$. Protoconch (Fig. 1G-H) small (W $0.75 \mathrm{~mm}$ ), protruding, of $1 \frac{1}{2}$ whorl; color yellow (Fig. $1 \mathrm{H}$ ); transition to teleoconch visible as a radial groove (Fig. 1G). Teleoconch with $\sim 3 \frac{1}{2}$ convex whorls, whorl profile rounded; sculpture of 3 evenly sized, spiny spiral cords (increasing in number, up to 8 on body whorl) separated by equally wide, deep interspaces; spines angular, large, spaced; on whorls 2 and beyond becoming partially hollow, scalelike (Fig. 1D); axial growth lines closely-packed, thin, more visible in interspaces between spiral cords. Suture barely visible. Aperture rounded, aperture height $\sim 1 / 3$ of shell height, white to light pinkish; inner lip thick, slightly flaring (Fig. 1A), producing short callus; outer lip slightly bending over aperture near whorl attachment (Fig. 1A, F). Shell base convex, sculptured by 4 spiral cords (with smaller spines than upper cords); periumbilical cord with larger, coarser nodules (Fig. 1C); umbilicus narrow, shallow. Operculum unknown.

Distribution: Known only from type locality.

Habitat: Coralline bottoms, 200-260 m.

Etymology: The specific name, a noun in apposition, is derived from the English common name of the Asian soapberry tree Litchi chinensis (Sapindaceae). The fruits of $L$. chinensis bear a strong resemblance to the shell of the described species, having similar coloration, globose outline, and an overall rough, "spiky" aspect.

Measurements (in mm): Holotype $5 \frac{1}{2} 2$ whorls, $\mathrm{H}=8.3$, $\mathrm{D}=7.5$.

Material examined: Types. Additional material: Syntype of Arene briareus var. perforata USNM 95025, Barbados, R/V Blake sta. 272, 139 m (05/iii/1879).

\section{DISCUSSION}

Compared to Western Atlantic congeners, Arene lychee sp. nov. is most similar to Arene briareus (Dall, 1881)

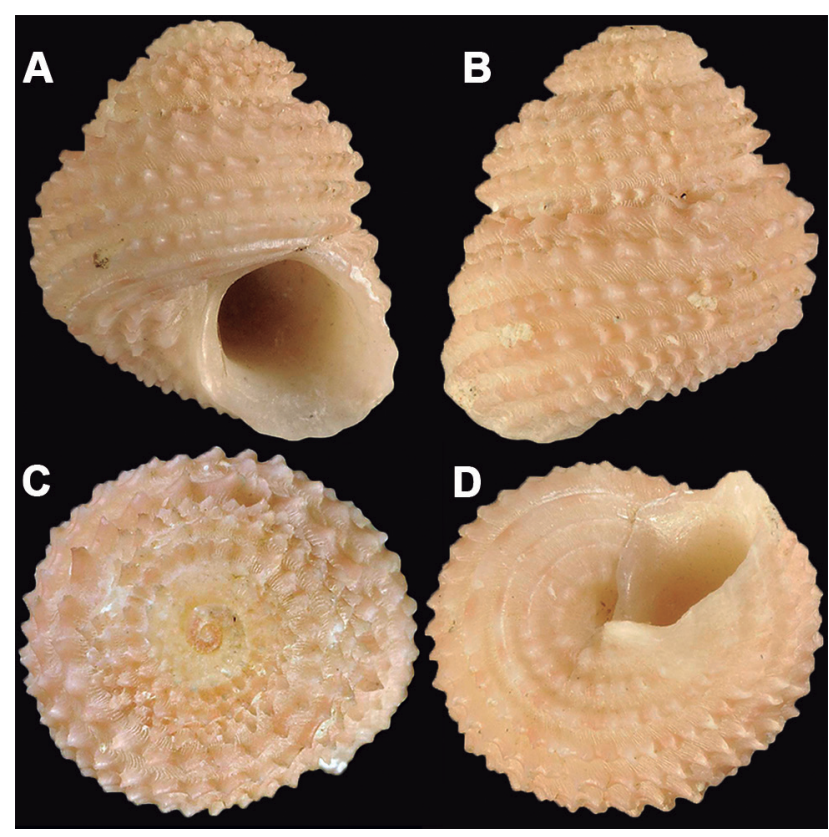

Figure 2. Arene briareus var. perforata Syntype USNM 95025; (A) apertural view $(H=8.0 \mathrm{~mm}, \mathrm{D}=7.3 \mathrm{~mm})$; (B) dorsal view; $(C)$ apical view; $(D)$ umbilical view.

from the Caribbean, in both color range and size, and seems to be related to it. Though the syntype specimen of Arene briareus var. perforata (Dall, 1889) (= Arene briareus) depicted herein (Fig. 2A-D) apparently has its color altered or damaged in some way, as it seems to be only faintly reddish, it certainly has a slightly yellowish apex, thus presenting a color pattern that is quite similar to A. lychee sp. nov. Even so, the new species differs by having one less spiral cord per whorl, bearing much larger, coarser, and more pronounced nodules/spines, and a proportionally taller, trochoid shell with a straighter profile. Moreover, it can be distinguished from nearly every other congener in Brazilian waters by its size alone, being at least $25 \%$ larger than the remaining species. The sole exception is Arene flexispina Leal \& Coelho, 1985, recently illustrated by Pimenta et al. (2014). It can be distinguished from the latter by having a predominantly red shell with a yellow apex, as opposed to an overall reddish-brown shell with lighter colored spiral cords and spines; more numerous nodules/spines; by being proportionally shorter and wider, and by having a less convex and more coarsely sculptured base.

The present discovery is based on relatively scarce samples but is nevertheless a testimony to the significance of studying seamount environments. Seamounts are known to harbor a diverse and often endemic biota (Stocks, 2004), which often suffers the effects of intense fishing pressure (Morato et al., 2004, 2006). In our understanding, Canopus is no exception to this fact, which is made even worse when a large number of new species that have been revealed from that location is considered. Since the fauna of Canopus might be at risk due to intense human activities in that area (Melo-Filho \& Melo, 2006), it is vital that the local biodiversity is thoroughly investigated so that proper legal protection can be provided. 


\section{ACKNOWLEDGEMENTS}

We are thankful to Carlo M. Cunha, Bárbara L.V. Romera, and the anonymous reviewers for several helpful suggestions, and to Lara Guimarães for the help with the SEM examinations.

\section{REFERENCES}

Abbate, D. \& Cavallari, D.C. 2013. A new species of Nassarius (Gastropoda, Nassariidae) from Canopus Bank, off Northeast Brazil. Papéis Avulsos de Zoologia, 53(1): 1-4.

Fernandes, M.R.; Garofalo, R. \& Pimenta, A.D. 2015. New species and records of Newtoniellinae (Caenogastropoda, Newtoniellidae) from Brazil. Journal of the Marine Biological Association of the United Kingdom, 95(4): 791-804.

McLean, J.H. 2012. New species and genera of colloniids from Indo-Pacific coral reefs, with the definition of a new subfamily Liotipomatinae n. subfam. (Turbinoidea, Colloniidae). ZooSystema, 34(2): 343-376.

Melo-Filho, G.A.S. \& Melo, G.A.S. 2006. A new species of the genus Munida Leach (Crustacea: Decapoda: Galatheidae) from the northeast coast of Brazil. Nauplius, 14(2): 49-54.
Morato, T.; Cheung, W.W.L. \& Pitcher, T.J. 2004. Vulnerability of seamount fish to fishing: fuzzy analysis of life-history attributes. Fisheries Centre Research Reports. Seamounts: Biodiversity and Fisheries, 12(5): 51-60.

Morato, T.; Cheung, W.W.L. \& Pitcher, T.J. 2006. Vulnerability of seamount fish to fishing: fuzzy analysis of life-history attributes. Journal of Fish Biology, 68(1): 209-221.

Pimenta, A.D.; Monteiro, J.C.; Barbosa, A.F.; Salgado, N.C. \& Coelho, A.C.S. 2014. Catalogue of the type specimens deposited in the Mollusca Collection of the Museu Nacional/UFRJ, Rio de Janeiro, Brazil. Zootaxa, 3780(1): 51-107.

Rios, E.C. 2009. Compendium of Brazilian Seashells. Rio Grande, Evangraf. Simone L.R.L. 2011. Phylogeny of the Caenogastropoda (Mollusca), based on comparative morphology. Arquivos de Zoologia, 42(4): 161-323.

Simone, L.R.L. \& Cunha, C.M. 2014. Taxonomical study on the mollusks collected in Marion-Dufresne (MD55) and other expeditions to SE Brazil: the Fissurellidae (Mollusca, Vetigastropoda). Zootaxa, 3835(4): 437-468.

Stocks, K. 2004. Seamount Invertebrates: Composition and vulnerability to fishing. Fisheries Centre Research Reports. Seamounts: Biodiversity and Fisheries, 12(5): 17-24.

Williams, S.T.; Karube, S. \& Ozawa, T. 2008. Molecular systematics of Vetigastropoda: Trochidae, Turbinidae and Trochoidea redefined. Zoologica Scripta, 35(5): 483-506. 